\title{
STUDI KOMPARASI PENINGKATAN MOTIVASI BELAJAR DAN RASA PERCAYA DIRI DENGAN METODE LAYANAN BIMBINGAN KELOMPOK ANTARA SISWA SMP NEGERI 15 YOGYAKARTA, SMP MUHAMMADIYAH 2 YOGYAKARTA DAN MTs NEGERI 2 YOGYAKARTA
}

\author{
Muntholib \\ Program Pasca Sarjana Magister Studi Islam \\ Universitas Muhammadiyah Yogyakarta \\ E-mail: gus_tholib@yahoo.com
}

\begin{abstract}
Abstrak
Penelitian bertujuan untuk mengetahui perbedaan peningkatkan motivasi belajar dan rasa percaya diri dengan metode layanan bimbingan kelompok pada siswa SMP N 15 Yogyakarta, SMP Muhammadiyah 2 Yogyakarta dan MTs N 2 Kota Yogyakarta. Penelitian ini merupakan penelitian tindakan kelas dengan desain cross sectional. Sampel penelitian adalah siswa SMP N 15 Yogyakarta, SMP Muhammadiyah 2 Yogyakarta dan MTs N II Kota Yogyakarta, masing-masing 10 siswa. Teknik analisis data menggunakan uji Mann Wihiteny-U, uji Wilxocon dan uji Kruskal Wallis. Hasil penelitian: 1) ada peningkatan motivasi belajar pada siswa SMP N 15 Yogyakarta, SMP Muhammadiyah 2 Yogyakarta dan MTs N 2 Kota Yogyakarta; 2) ada peningkatan rasa percaya diri pada siswa; 3) ada perbedaan peningkatan motivasi belajar pada siswa; 4) ada perbedaan peningkatan rasa percaya diri pada siswa.
\end{abstract}

Kata kunci: motivasi, rasa percaya diri, layanan bimbingan kelompok

\begin{abstract}
The objective of this research is to know the difference of learning motivation and selfconfidence with the method of group guidance service at SMP N 15 Yogyakarta, SMP Muhammadiyah 2 Yogyakarta and MTs $N 2$ Yogyakarta. This research is a class action research with cross sectional design. The sample of the study were students of SMP N 15 Yogyakarta, SMP Muhammadiyah 2 Yogyakarta and MTs N II Kota Yogyakarta, each 10 students. Data analysis technique using Mann Wihiteny-U test, Wilxocon test and Kruskal Wallis test. Result of research: 1) there is an increase of learning motivation in students of SMP N 15 Yogyakarta, SMP Muhammadiyah 2 Yogyakarta and MTs N 2 Yogyakarta City; 2) there is increased self-confidence in students; 3) there is a difference in the increase of learning motivation in students; 4) there is a difference in self-confidence in students.
\end{abstract}

Keywords: motivation, confidence, group guidance services

\section{Info Artikel}

Diterima Februari 2018, disetujui Maret 2018, diterbitkan Juni 2018 


\section{PENDAHULUAN}

Pencapaian prestasi dalam dunia pendidikan merupakan sebuah konsekuensi multidimensional yang menghubungkan berbagai faktor termasuk keluarga, komunitas, sekolah, teman sebaya, dan siswa itu sendiri. Faktor internal yang berasal dari diri mahasiswa yang mempengaruhi prestasi belajar adalah faktor jasmaniah, faktor psikologis atau emosional dan faktor kelelahan, sedangkan faktor eksternal yang mempengaruhi prestasi belajar siswa adalah faktor keluarga, faktor masyarakat/lingkungan dan faktor sekolah (Slameto, 2011: 54 - 72).

Motivasi sangat diperlukan dalam proses belajar, karena motivasi merupakan pendorong yang mengubah energi dalam diri seseorang siswa ke dalam bentuk aktivitas nyata untuk mencapai cita-cita (Djamarah, 2012: 148). Seorang siswa yang mempunyai motivasi belajar mempunyai kemauan dan keinginan untuk melakukan pendekatan belajar sesuai dengan motif yang dimilikinya (Purwanto, 2013: 60).

Kepercayaan diri pada siswa merupakan keseluruhan gambaran diri yang meliputi persepsi mahasiswa tentang diri, perasaan, keyakinan dan nilai-nilai yang berhubungan dengan dirinya terkait dengan cita-cita dan harapan (Desmita, 2010: 166).

Kemampuan menyelesaikan tugas pada siswa, dipengaruhi oleh tingkat kepercayaan dirinya yang merupakan salah satu dari sifat kepribadian seseorang. Sifat kepribadian ini bukan faktor bawaan, tetapi diperoleh dari pengalaman hidup, diajarkan dan ditanamkan orang lain yang terdekat atau dari lingkungan sekitarnya (Purwanto, 2013: 44).

Berdasarkan hasil penelitian, Davidson, et.al (2006: 65) menjelaskan bahwa kepercayaan diri dapat membantu seseorang untuk mengatasi masalah atau tugas yang dihadapinya dengan menghilangkan keraguan yang ada di dalam hatinya. Individu yang memiliki kepercayaan diri mengetahui apa yang dibutuhkan dalam hidupnya dan dapat lebih mudah mengambil langkah yang tepat untuk penyelesaian masalah dengan penuh keyakinan. Kepercayaan diri membantunya untuk menyelesaikan tugas yang sedang dihadapinya dengan baik. Menurut Aderson, et. al. (2004: 32) dalam penelitiannya disebutkan bahwa kepercayaan diri yang dimiliki seseorang dapat meningkatkan harapan untuk meraih keberhasilan termasuk di dalamnya meningkatkan kemampuan menyelesaikan tugas dan mencapai prestasi setinggi-tingginya. Dengan adanya kepercayaan diri yang tinggi menumbuhkan kemampuan diri yang tinggi pula.

Berdasarkan uraian di atas dapat diperoleh gambaran bahwa motivasi belajar dan kepercayaan diri merupakan faktor internal yang mempunyai peran penting dalam pencapaian sesuatu hal yang baik 
misal cita-cita, prestasi belajar atau hal-hal lainnya. Permasalahan motivasi belajar dan kepercayaan diri yang rendah yang dialami sekelompok siswa dapat diatasi dengan memberikan layanan bimbingan secara kelompok agar membantu siswa dapat meningkatkan prestasi belajarnya. Bimbingan kelompok dengan ceramah memberikan layanan bimbingan kelompok dengan memberikan informasi dan pengetahuan mellaui penjelasan guru. dengan diskusi kelompok memberikan layanan bimbingan kelompok dengan mengajak siswa mendiskusikan masalah yang dialami bersama kelompoknya untuk mengidentifikasi dan menemukan cara-cara mengatasi masaalah. Sedangkan teknik bimbigan kelompok dengan teknik pencipta suasana kekeluargaan (homeroom) memberikan layanan bimbingan kelompok dengan suasana akrab dan hangat di luar kelas membantu siswa menbemukan masalahnya secara lebih terbuka.

SMP N 15 Yogyakarta, SMP Muhammadiyah 2 dan MTs N II Kota Yogyakarta memiliki karakter yang berbeda-beda, antara lain dilihat dari status sekolah yaitu menengah negeri, menengah swasta ataupun madrasah, nilai yang diperoleh setiap siswa untuk memasuki sekolah, minat siswa untuk menjadi murid, status ekonomi dan sosial orang tua siswa. Berdasarkan hasil wawancara pada 6 siswa pada ketiga sekolah tersesut menunjukkan siswa masih terdapat siswa yang mempunyai dorongan untuk mencapai prestasi belajar di sekolah karena merasa kurang pandai dan siswa yang mempunyai belum motivasi untuk berprestasi tersbut mempunyai rasa percaya diri yang rendah karena siswa tidak yakin bahwa dirinya mampun menyelesaikan tugas sebagai siswa.

Upaya untuk memperbaiki dan meningkatkan motivasi belajar dan rasa percaya diri dapat dilakukan melalui layanan bimbingan kelompok. Layanan bimbingan kelompok ini merupakan layanan bimbingan yang memungkinkan sejumlah siswa secara bersama-sama memperoleh berbagai pemahaman mengenai motivasi belajar dan rasa percaya diri untuk meningkatkan prestasi belajar sehingga siswa mampu mengambil keputusan untuk mengatasi kesulitan memupuk motivasi belajar dan rasa percaya diri dengan strategi yang tepat dan efisien untuk meningkatkan hasil belajar. Layanan bimbingan kelompok ini dilakukan secara bersama-sama atau berkelompok kepada sejumlah individu mempunyai permasalahan sejenis, yaitu motivasi belajar dan rasa percaya diri rendah.

Berdasarkan paparan di atas penulis tertarik melakukan penelitian untuk meningkatkan motivasi belajar, dan kepercayaan diri siswa dengan metode metode Layanan Bimbingan Kelompok, dengan judul "Komparasi Peningkatkan Motivasi Belajar dan Rasa Percaya Diri dengan Metode Layanan Bimbingan Kelompok pada siswa SMP N 15 Yogyakarta, SMP 
Muhammadiyah 2 Yogyakarta dan MTs N 2 Kota Yogyakarta”.

\section{METODE PENELITIAN}

Penelitian ini merupakan penelitian tindakan kelas (classroom action research) dengan menggunakan desain cross sectional. Penelitian ini dilaksanakan pada siswa VIII G SMP N 15 Yogyakarta, kelas IX E SMP Muhammadiyah 2 Yogyakarta dan kelas VIII A MTs N II Kota Yogyakarta semester genap tahun ajaran 2015/2016. Teknik pengambilan sampel menggunakan purposive sampling, masing-masing berjumlah 10 siswa berdasarkan nilai angket pre-test motivasi belajar dan percaya diri.

Variabel bebas dalam penelitian ini adalah bimbingan kelompok meliputi teknik pemberian informasi (metode ceramah), teknik diskusi kelompok, dan teknik pencipta suasana kekeluargaan (homeroom), dan variabel terikat yaitu motivasi belajar dan percaya diri. Prosedur penelitian tindakan kelas dalam penelitian ini menggunakan model Kurt Lewin yang terdiri dari empat komponen yaitu perencanaan (rancangan), perlakuan (tindakan), pengamatan dan refleksi.

Instrumen pengambilan data menggunkan angket dengan skala Likert. Metode analisis data meliputi analisis univariat dengan rata-rata (mean), standar deviasi, nilai minimum, nilai maksimum dan persentase; analisis bivariat dengan uji
Wilcoxon, uji Mann-Whitney U, dan uji Kruskal-Wallis.

\section{HASIL PENELITIAN}

Pengujian hipotesis dengan uji Wilcoxon menggunakan bantuan komputer SPSS: 1) Hipotesis nihil (H0) yang diajukan berbunyi "tidak ada peningkatan motivasi belajar melalui layanan bimbingan kelompok pada siswa SMP N 15 Yogyakarta, SMP Muhammadiyah 2 Yogyakarta dan MTs N 2 Kota Yogyakarta" Ditolak.

Sedangkan hipotesis alternatif (Ha) yang diajukan "ada peningkatan motivasi belajar melalui layanan bimbingan kelompok pada pada siswa SMP N 15 Yogyakarta, SMP Muhammadiyah 2 Yogyakarta dan MTs N 2 Kota Yogyakarta" diterima sehingga teruji kebenarannya. 2) Hipotesis nihil (H0) yang diajukan berbunyi "tidak ada peningkatan rasa percaya diri melalui layanan bimbingan kelompok pada siswa SMP N $15 \quad$ Yogyakarta, SMP Muhammadiyah 2 Yogyakarta dan MTs N 2 Kota Yogyakarta" Ditolak. Sedangkan hipotesis alternatif (Ha) yang diajukan "ada peningkatan rasa percaya diri melalui layanan bimbingan kelompok pada pada siswa SMP N 15 Yogyakarta, SMP Muhammadiyah 2 Yogyakarta dan MTs N 2 Kota Yogyakarta" diterima sehingga teruji kebenarannya.

Pengujian hipotesis dengan uji Wilcoxon menggunakan bantuan komputer SPSS: 1) Hipotesis nihil 
(H0) yang diajukan berbunyi "tidak ada perbedaan motivasi belajar melalui layanan bimbingan kelompok pada siswa SMP N 15 Yogyakarta, SMP Muhammadiyah 2 Yogyakarta dan MTs N 2 Kota Yogyakarta" Ditolak. Sedangkan hipotesis alternatif (Ha) yang diajukan "ada perbedaan motivasi melalui layanan bimbingan kelompok pada pada siswa SMP N 15 Yogyakarta, SMP Muhammadiyah 2 Yogyakarta dan MTs N 2 Kota Yogyakarta" diterima sehingga teruji kebenarannya. 2) Hipotesis nihil (H0) yang diajukan berbunyi "tidak ada perbedaan rasa percaya diri melalui layanan bimbingan kelompok pada siswa SMP N 15 Yogyakarta, SMP Muhammadiyah 2 Yogyakarta dan MTs N 2 Kota Yogyakarta" Diterima. Sedangkan hipotesis alternatif (Ha) yang diajukan "ada peningkatan rasa percaya diri melalui layanan bimbingan kelompok pada pada siswa SMP N 15 Yogyakarta, SMP Muhammadiyah 2 Yogyakarta dan MTs N 2 Kota Yogyakarta" ditolak sehingga tidak teruji kebenarannya.

Pengujian hipotesis dengan uji Kruskal Wallis tersebut menggunakan bantuan komputer SPSS maka: 1) Hipotesis nihil (H0) yang diajukan berbunyi "tidak ada perbedaan peningkatan motivasi belajar melalui layanan bimbingan kelompok pada siswa SMP N 15 Yogyakarta, SMP Muhammadiyah 2 Yogyakarta dan MTs N 2 Kota Yogyakarta" Ditolak. Sedangkan hipotesis alternatif (Ha) yang diajukan "ada peningkatan peningkatan motivasi belajar melalui layanan bimbingan kelompok pada pada siswa SMP N 15 Yogyakarta, SMP Muhammadiyah 2 Yogyakarta dan MTs N 2 Kota Yogyakarta" diterima sehingga teruji kebenarannya. 2) Hipotesis nihil (HO) yang diajukan berbunyi "tidak ada perbedaan peningkatan rasa percaya diri melalui layanan bimbingan kelompok pada siswa SMP N 15 Yogyakarta, SMP Muhammadiyah 2 Yogyakarta dan MTs N 2 Kota Yogyakarta" Diterima. Sedangkan hipotesis alternatif (Ha) yang diajukan "ada perbedaan peningkatan rasa percaya diri melalui layanan bimbingan kelompok pada pada siswa SMP N 15 Yogyakarta, SMP Muhammadiyah 2 Yogyakarta dan MTs N 2 Kota Yogyakarta" ditolak sehingga tidak teruji kebenarannya.

Pengujian hipotesis dengan uji Mann Whiteny U menggunakan bantuan komputer SPSS: 1) Hipotesis nihil (H0) yang diajukan berbunyi "tidak ada perbedaan motivasi belajar melalui layanan bimbingan kelompok pada siswa SMP N 15 Yogyakarta (metode ceramah) dengan SMP Muhammadiyah 2 Yogyakarta (metode diskusi)" diterima sehingga teruji kebenarannya Sedangkan hipotesis alternatif (Ha) yang diajukan "ada perbedaan motivasi melalui layanan bimbingan kelompok pada pada siswa SMP N 15 Yogyakarta metode ceramah) dengan SMP Muhammadiyah 2 Yogyakarta (metode diskusi)" ditolak sehingga 
tidak teruji kebenarannya. 2) Hipotesis nihil (H0) yang diajukan berbunyi "tidak ada perbedaan motivasi belajar melalui layanan bimbingan kelompok pada siswa SMP N 15 Yogyakarta (metode ceramah) MTs N 2 Kota Yogyakarta (metode hommeroom)" diterima sehingga teruji kebenarannya. Sedangkan hipotesis alternatif (Ha) yang diajukan "ada perbedaan motivasi melalui layanan bimbingan kelompok pada pada siswa SMP N 15 Yogyakarta metode ceramah) dengan MTs N 2 Kota Yogyakarta (metode hommeroom)" ditolak sehingga tidak terbukti kebenarannya. 3) Hipotesis nihil (H0) yang diajukan berbunyi "tidak ada perbedaan motivasi belajar melalui layanan bimbingan kelompok pada siswa SMP Muhammadiyah 2 Yogyakarta (metode diskusi) MTs N 2 Kota Yogyakarta (metode hommeroom)" Ditolak sehingga tidak teruji kebenarannya. Sedangkan hipotesis alternatif $(\mathrm{Ha})$ yang diajukan "ada perbedaan motivasi melalui layanan bimbingan kelompok pada pada siswa SMP Muhammadiyah 2 Yogyakarta (metode diskusi) dengan MTs N 2 Kota Yogyakarta (metode hommeroom)" diterima sehingga teruji kebenarannya.

Hasil pengujian dapat disimpulkan bahwa ada perbedaan yang sangat signifikan antara motivasi belajar sebelum dan setelah diberi layanan bimbingan kelompok. Setelah dicermati lebih lanjut terhadap pada siswa yang mendapat layanan bimbingan kelompok dengan teknik pemberian informasi (metode ceramah) mengalami peningkatan motivasi belajar diperoleh rerata sebelum diberi tindakan adalah 93,67 dan rerata setelah diberi layanan bimbingan kelompok dengan teknik pemberian informasi (metode ceramah) adalah 124,47.

$$
\text { Hasil pengujian dapat }
$$

disimpulkan bahwa ada perbedaan yang sangat signifikan antara motivasi belajar sebelum dan setelah diberi layanan bimbingan kelompok. Setelah dicermati lebih lanjut terhadap pada siswa yang mendapat layanan bimbingan kelompok dengan teknik pemberian informasi (metode ceramah) mengalami peningkatan motivasi belajar diperoleh rerata sebelum diberi tindakan adalah 93,67 dan rerata setelah diberi layanan bimbingan kelompok dengan teknik pemberian informasi (metode ceramah) adalah 124,47.

Hal ini menunjukkan terdapat selisih rerata motivasi belajar dan setelah kegiatan sebesar 30,80 poin atau telah terjadi kenaikan sebesar $32,88 \%$ dari hasil pre-test. Siswa yang mendapat layanan bimbingan kelompok dengan teknik diskusi mengalami peningkatan peningkatan motivasi belajar diperoleh rerata sebelum diberi tindakan adalah 91,80 dan rerata setelah diberi layanan bimbingan kelompok dengan teknik diskusi adalah 131,37. Hal ini menunjukkan terdapat selisih rerata motivasi belajar dan setelah kegiatan sebesar 39,47 poin atau telah terjadi 
kenaikan sebesar 42,99\% dari hasil pre-test. Siswa yang mendapat layanan bimbingan kelompok dengan teknik pencipta suasana kekeluargaan (homeroom) mengalami peningkatan peningkatan motivasi belajar diperoleh rerata sebelum diberi tindakan adalah 90,33 dan rerata setelah diberi layanan bimbingan kelompok dengan teknik diskusi adalah 111,40. Hal ini menunjukkan terdapat selisih rerata motivasi belajar dan setelah kegiatan sebesar 21,07 poin atau telah terjadi kenaikan sebesar 23,32\% dari hasil pre-test.

Hasil pengujian dapat disimpulkan bahwa ada perbedaan yang sangat signifikan antara rasa percaya diri sebelum dan setelah diberi layanan bimbingan kelompok. Setelah dicermati lebih lanjut terhadap pada siswa yang mendapat layanan bimbingan kelompok dengan teknik pemberian informasi (metode ceramah) mengalami peningkatan rasa pecaya diri diperoleh rerata sebelum diberi tindakan adalah 101,93 dan rerata setelah diberi layanan bimbingan kelompok dengan teknik pemberian informasi (metode ceramah) adalah 117,13 . Hal ini menunjukkan terdapat selisih rerata rasa percaya diri dan setelah kegiatan sebesar 19,07 poin atau telah terjadi kenaikan sebesar $18,70 \%$ dari hasil pre-test. Siswa yang mendapat layanan bimbingan kelompok dengan teknik diskusi mengalami peningkatan peningkatan rasa percaya diri diperoleh rerata sebelum diberi tindakan adalah 100,80 dan rerata setelah diberi layanan bimbingan kelompok dengan teknik diskusi adalah 118,33. Hal ini menunjukkan terdapat selisih rerata rasa percaya diri dan setelah kegiatan sebesar 202,00 poin atau telah terjadi kenaikan sebesar 20,03\% dari hasil pre-test. Siswa yang mendapat layanan bimbingan kelompok dengan teknik pencipta suasana kekeluargaan (homeroom) mengalami peningkatan peningkatan rasa percaya diri diperoleh rerata sebelum diberi tindakan adalah 102,73 dan rerata setelah diberi layanan bimbingan kelompok dengan teknik diskusi adalah 114,47. Hal ini menunjukkan terdapat selisih rerata motivasi belajar dan setelah kegiatan sebesar 14,27 poin atau telah terjadi kenaikan sebesar 13,89\% dari hasil pre-test.

Hasil pengujian dengan uji Mann Whiteny U menunjukkan: 1) tidak ada perbedaan motivasi pada kelompok yang memperleh layanan bimbingan kelompok dengan metode ceramah dengan kelompok yang mendapat layanan bimbingan kelompok metode diskusi. 2) ada perbedaan motivasi pada kelompok yang memperleh layanan bimbingan kelompok dengan metode ceramah dengan kelompok yang mendapat layanan bimbingan kelompok metode homeroom. 3) tidak ada perbedaan motivasi pada kelompok yang memperleh layanan bimbingan kelompok dengan metode diskusi dengan kelompok yang mendapat 
layanan bimbingan kelompok metode homeroom. Hasil penelitian ini menunjukkan metode ceramah dan diskusi mampu meningkatkan motivasi lebih tinggi dibandingkan metode homeeroom, dan metode ceramah dan metode diskusi mempunyai efektivitas yang sama dalam meningkatkan motivasi siswa.

Hasil pengujian menunjukkan bahwa siswa layanan bimbingan kelompok dengan teknik diskusi mempunyai peningkatan motivasi belajar lebih tinggi dibandingkan dengan siswa yang mendapat layanan bimbingan kelompok dengan teknik pemberian informasi (metode ceramah) maupun siswa yang mendapat layanan bimbingan kelompok dengan pencipta suasana kekeluargaan (homeroom). Hasil pengujian juga menunjukkan bahwa layanan bimbingan kelompok dengan teknik pemberian informasi (metode ceramah) mempunyai peningkatan motivasi belajar lebih tinggi dibandingkan siswa yang mendapat layanan bimbingan kelompok dengan teknik pencipta suasan kekeluargaan (homeroom). Hal ini menunjukkan bahwa layanan bimbingan kelompok dengan teknik diskusi mempunyai pengaruh yang lebih kuat dalam meningkatkan motivasi belajar dibandingkn dengan teknik pemberian informasi (metode ceramah) maupun teknik pencipta suasana kekeluargaan (homeroom).

Hasil pengujian menunjukkan bahwa siswa layanan bimbingan kelompok dengan layanan bimbingan kelompok dengan teknik pemberian informasi (metode ceramah), teknik diskusi maupun teknik pencipta suasana kekeluargaan (homeroom) tidak mempunyai perbedaan peningkatan rasa percaya diri. Hasil pengujian juga menunjukkan bahwa layanan bimbingan kelompok dengan teknik pemberian informasi (metode ceramah), teknik diskusi maupun teknik pencipta suasana kekeluargaan (homeroom) mempunyai mempunyai pengaruh yang sama besarnya dalam meningkatkan rasa percaya diri.

Berdasarkan keterangan di atas, maka dapat disimpulkan bahwa: 1) "ada peningkatan motivasi belajar pada siswa SMP N 15 Yogyakarta, SMP Muhammadiyah 2 Yogyakarta dan MTs N 2 Kota Yogyakarta"; 2) "ada peningkatan rasa percaya diri pada siswa SMP N 15 Yogyakarta, SMP Muhammadiyah 2 Yogyakarta dan MTs N 2 Kota Yogyakarta"; 3) ada perbedaan peningkatan motivasi belajar pada siswa SMP N 15 Yogyakarta, SMP Muhammadiyah 2 Yogyakarta dan MTs N 2 Kota Yogyakarta", 4) "ada perbedaan peningkatan rasa percaya diri pada siswa SMP N 15 Yogyakarta, SMP Muhammadiyah 2 Yogyakarta dan MTs N 2 Kota Yogyakarta.

\section{PEMBAHASAN}

Hasil analisis data menunjukkan bahwa "pelaksanaan layanan bimbingan kelompok dapat meningkatkan motivasi belajar dan 
rasa percaya diri pada siswa SMP N 15 Yogyakarta, SMP Muhammadiyah 2 Yogyakarta dan MTs N 2 Kota Yogyakarta". Meningkatnya motivasi belajar dan rasa percaya diri tersebut dapat diketahui dari hasil observasi dan pemberian angket pre-test dan post-test motivasi belajar dan rasa percaya diri.

Hasil penelitian menunjukkan setelah mendapatkan layanan bimbingan kelompok dengan teknik pemberian informasi (metode ceramah) telah terjadi peningkatan motivasi belajar yaitu sejumlah 8 siswa $\quad(53,33 \%) \quad$ mengalami peningkatan motivasi belajar dari kategori sedang menjadi tinggi dan sejumlah 7 siswa $(46,67 \%)$ mengalami peningkatan motivasi belajar dari rendah menjadi sedang. Setelah mendapatkan layanan bimbingan kelompok dengan teknik diskusi, telah terjadi peningkatan motivasi belajar yaitu sejumlah 8 siswa $(53,33 \%)$ mengalami peningkatan motibasi belajar dari kategori sedang menjadi tinggi, sejumlah 6 siswa $(40 \%)$ mengalami peningkatan motivasi belajar dari rendah menjadi sedang, dan sejumlah 1 siswa $(6,67 \%)$ tidak mengalami peningkatan motivasi belajar yaitu tetap pada kategori sedang. Setelah mendapatkan layanan bimbingan kelompok dengan teknik pecipta suasana kekeluargaan (homeroom), telah terjaadi peningkatan motivasi belajar yaitu sejumlah $\quad 10$ siswa $(66,67 \%)$ mengalami peningkatan motivasi belajar dari kategori sedang menjadi tinggi, sejumlah 3 siswa (20\%) mengalami peningkatan motivasi belajar dari kategori sedang menjadi tinggi dan sejumlah 2 siswa $(13,33 \%)$ mengalami peningkatan motivasi belajar dari rendah menjadi tinggi.

Hasil penelitian menunjukkan setelah pelaksanaan layanan bimbingan kelompok dengan teknik pemberian informasi (metode ceramah), telah terjadi peningkatan rasa percaya diri yaitu sejumlah 4 siswa $\quad(26,67 \%) \quad$ mengalami peningkatan rasa percaya diri dari kategori sedang menjadi tinggi, sejumlah 3 siswa (20\%) mengalami peningkatan rasa percaya diri dari kategori rendah menjadi sedang, dan sejumlah sejumlah 6 siswa $(40 \%)$ tidak mengalami peningkatan rasa percaya diri tetap pada kondisi sedang. Setelah pelaksanaan layanan bimbingan kelompok dengan teknik diskusi, telah terjadi peningkatan rasa percaya diri yaitu sejumlah 5 siswa $(33,33 \%)$ mengalami peningkatan rasa percaya diri dari kategori sedang menjadi tinggi, sejumlah 3 siswa (20\%) mengalami peningkatan rasa percaya diri dari kategori rendah menjadi sedang, dan sejumlah sejumlah 7 siswa $(46,67 \%)$ tidak mengalami peningkatan rasa percaya diri tetap pada kondisi sedang. Setelah pelaksanaan layanan bimbingan kelompok dengan teknik pencipta suasana kekeluargaan (homeroom), telah terjadi peningkatan rasa percaya diri yaitu sejumlah 3 siswa (20\%) 
mengalami peningkatan rasa percaya diri dari kategori sedang menjadi tinggi, sejumlah 3 siswa $(20 \%)$ mengalami peningkatan rasa percaya diri dari kategori rendah menjadi sedang, dan sejumlah 9 siswa (60\%) tidak mengalami peningkatan rasa percaya diri tetap pada kondisi sedang.

Hasil pengujian ini
menunjukkan ada perbedaan yang sangat signifikan antara motivasi belajar sebelum dan setelah diberi layanan bimbingan kelompok. Setelah dicermati lebih lanjut terhadap pada siswa yang mendapat layanan bimbingan kelompok dengan teknik pemberian informasi (metode ceramah) mengalami peningkatan peningkatan motivasi belajar diperoleh rerata sebelum diberi tindakan adalah 93,67 dan rerata setelah diberi layanan bimbingan kelompok dengan teknik pemberian informasi (metode ceramah) adalah 124,47, sehingga terdapat selisih rerata motivasi belajar dan setelah kegiatan sebesar 30,80 poin atau telah terjadi kenaikan sebesar 32,88\% dari hasil pre-test. Siswa yang mendapat layanan bimbingan kelompok dengan teknik diskusi mengalami peningkatan peningkatan motivasi belajar diperoleh rerata sebelum diberi tindakan adalah 91,80 dan rerata setelah diberi layanan bimbingan kelompok dengan teknik diskusi adalah 131,37, sehingga terdapat selisih rerata motivasi belajar dan setelah kegiatan sebesar 39,47 poin atau telah terjadi kenaikan sebesar 42,99\% dari hasil pre-test.
Siswa yang mendapat layanan bimbingan kelompok dengan teknik pencipta suasana kekeluargaan (homeroom) mengalami peningkatan peningkatan motivasi belajar diperoleh rerata sebelum diberi tindakan adalah 90,33 dan rerata setelah diberi layanan bimbingan kelompok dengan teknik diskusi adalah 111,40, sehingga terdapat selisih rerata motivasi belajar dan setelah kegiatan sebesar 21,07 poin atau telah terjadi kenaikan sebesar $23,32 \%$ dari hasil pre-test.

$$
\text { Hasil pengujian ini }
$$
menunjukkan ada perbedaan yang sangat signifikan antara rasa percaya diri sebelum dan setelah diberi layanan bimbingan kelompok. Setelah dicermati lebih lanjut terhadap pada siswa yang mendapat layanan bimbingan kelompok dengan teknik pemberian informasi (metode ceramah) mengalami peningkatan peningkatan rasa pecaya diri diperoleh rerata sebelum diberi tindakan adalah 101,93 dan rerata setelah diberi layanan bimbingan kelompok dengan teknik pemberian informasi (metode ceramah) adalah 117,13, sehingga terdapat selisih rerata rasa percaya diri dan setelah kegiatan sebesar 19,07 poin atau telah terjadi kenaikan sebesar $18,70 \%$ dari hasil pre-test. Siswa yang mendapat layanan bimbingan kelompok dengan teknik diskusi mengalami peningkatan peningkatan rasa percaya diri diperoleh rerata sebelum diberi tindakan adalah 100,80 dan rerata setelah diberi layanan bimbingan 
kelompok dengan teknik diskusi adalah 118,33, sehingga terdapat selisih rerata rasa percaya diri dan setelah kegiatan sebesar 20,20 poin atau telah terjadi kenaikan sebesar 20,03\% dari hasil pre-test. Siswa yang mendapat layanan bimbingan kelompok dengan teknik pencipta suasana kekeluargaan (homeroom) mengalami peningkatan peningkatan rasa percaya diri diperoleh rerata sebelum diberi tindakan adalah 102,73 dan rerata setelah diberi layanan bimbingan kelompok dengan teknik diskusi adalah 114,47, sehingga terdapat selisih rerata motivasi belajar dan setelah kegiatan sebesar 14,27 poin atau telah terjadi kenaikan sebesar 13,89\% dari hasil pre-test.

Peningkatan motivasi belajar dan rasa percaya diri waktu berdasarkan hasil observasi diketahui bahwa ada peningkatan respon dan aktivitas siswa pada setiap siklus tindakan. Pada siklus I siswa terlihat kurang antusias dalam mengikuti bimbingan, enggan menyampaikan pendapat. Siswa belum bisa berinteraksi dan bekerjasama dengan baik sehingga diskusi belum berjalan dengan lancar. Siklus II siswa sudah mulai aktif dalam tanya jawab, diskusi dan terjalin interaksi serta kerjasama yang baik. Pada siklus II pemberian layanan dirasa sudah cukup karena sudah ada peningkatan motivasi dan rasa percaya diri. Siswa sudah aktif mengemukakan pendapat, bisa berinteraksi dan bekerjasama dengan baik. Saling menghormati dan menghargai pendapat orang lain sehingga siswa sudah dapat memahami pentingnya motivasi belajar dan rasa peercaya diri untuk mencapai prestasi belajar yang maskimal. Setelah melihat hasil observsi yang dicapai setiap siswa dalam setiap siklus tindakan, maka terdapat peningkatan motivasi belajar dan rasa percaya diri. Dengan demikian hipotesis yang diajukan dalam penelitian ini teruji kebenarannya.

Hal ini menunjukkan bahwa motivasi belajar dan rasa percaya diri dapat ditingkatkan melalui layanan bimbingan kelompok dengan teknik pemberian informasi (metode ceramah), diskusi, dan pencipta suasana kekeluargaan (homeroom). Teknik pemberian informasi, diskusi dan pencipta suasana kekeluargaan merupakan teknik-teknik bimbingan kelompok yang yang dapat digunakan untuk meningkatan motivasi belajar dan rasa percaya diri karena pada saat diterapkan dalam membimbing dan melatih siswa dalam meningkatkan mptivasi belajar dan rasa percaya diri terbukti kebenarannya. Karena dengan bimbingan kelompok dengan teknik pemberian informasi (metode ceramah), diskusi, dan pencipta suasana kekeluargaan (homeroom) siswa dapat mengetahui dan memhamani bagaimana motivasi belajar dan percaya diri sehingga siswa dapat memperbaiki motivasi dan rasa percaya diri secara tepat setelah diberikan layanan. 
Hasil penelitian ini memberikan informasi bahwa layanan bimbingan kelompok dengan metode pemberian informasi (metode ceramah), diskusi, dan pencipta suasana kekeluargaan (homeroom) memberikan efektivitas yang berbeda terhadap peningkatan motivasi siswa. Metode ceramah dan diskusi memberikan efektivitas yang sama terhadap penigkatan motivas, dan metode homeroom memberikan peningkatan motivasi lebih rendah dibandingkan metode ceramah dan metode diskusi. Sedangkan terhadap peningkatan rasa percaya diri layanan bimbingan kelompok dengan metode pemberian informasi (metode ceramah), diskusi, dan pencipta suasana kekeluargaan (homeroom) memberikan efektivitas yang sama.

Berdasarkan hasil penelitian ini, peneliti menyimpulkan bahwa dengan layanan bimbingan kelompok, siswa dapat menggali pengalaman yang terungkap dalam tanya jawab, diskusi dan interaksi dalam kelompok sehingga dapat memetakan masalah dalam rendahnya motivasi dan rasa percaya diri, menetapkan kesalahan dalam memperbaiki motivasi dan rasa percaya diri. Kegiatan bimbingan kelompok dengan teknik pemberian informasi (metode ceramah), diskusi, dan pencipta suasana kekeluargaan (homeroom) untuk meningkatkan motivasi belajar dan rasa percaya diri diharapkan dapat memperbaiki kesalahan dalam memperbaiki perilaku sehari-hari yang dialami siswa.

\section{KESIMPULAN DAN SARAN \\ Kesimpulan}

Berdasarkan analisis data dan pengujian dapat disimpulkan bahwa:

1. Pelaksanaan kegiatan layanan bimbingan kelompok dapat meningkatkan motivasi belajar pada siswa SMP N 15 Yogyakarta, SMP Muhammadiyah 2 Yogyakarta dan MTs N 2 Kota Yogyakarta yaitu layanan bimbingan kelompok dengan teknik pemberian informasi (metode ceramah) memberikan pengaruh peningkatan motivasi belajar tertinggi dan layanan bimbingan kelompok dengan teknik pencipta suasana kekeluargaan (homeroom) memberikan pengaruh peningkatan motivasi belajar terendah.

2. Pelaksanaan kegiatan layanan bimbingan kelompok dapat meningkatkan rasa percaya diri $\begin{array}{llll}\text { pada siswa SMP } & \text { N } 15\end{array}$ Yogyakarta, SMP Muhammadiyah 2 Yogyakarta dan MTs N 2 Kota Yogyakarta yaitu layanan bimbingan kelompok dengan teknik pencipta suasana kekeluargaan (homeroom) memberikan pengaruh peningkatan rasa percaya diri tertinggi dan layanan bimbingan kelompok dengan teknik diskusi memberikan pengaruh peningkatan rasa percaya diri terendah. 
3. Perbedaan pelaksanaan kegiatan layanan bimbingan kelompok dengan teknik pemberian informasi (metode ceramah), teknik diskusi dan teknik pencipta suasana kekeluargaan (homeroom) menyebabkan adanya perbedaan peningkatkan motivasi pada siswa SMP N 15 Yogyakarta, SMP Muhammadiyah 2 Yogyakarta dan MTs N 2 Kota Yogyakarta. Layanan bimbingan kelompok dengan teknik diskusi menyebabkan peningkatan motivasi belajar lebih tinggi dibandingkan layanan bimbingan kelompok dengan teknik pemberian informasi (metode ceramah) maupun layanan bimbingan kelompok dengan teknik pecipta suasana kekeluargaan (hoomeroom); dan layanan bimbingan kelompok dengan teknik pemberian informasi (metode ceramah) menyebabkan peningkatan motivasi belajar lebih tinggi dibandikan layanan bimbingan kelompok dengan teknik pecipta suasana kekeluargaan (hoomeroom).

4. Perbedaan pelaksanaan kegiatan layanan bimbingan kelompok dengan teknik pemberian informasi (metode ceramah), teknik diskusi dan teknik pencipta suasana kekeluargaan (homeroom) tidak menyebabkan adanya perbedaan peningkatkan rasa percaya diri pada siswa SMP

N 15 Yogyakarta, SMP Muhammadiyah 2 Yogyakarta dan MTs N 2 Kota Yogyakarta.

\section{Rekomendasi}

Rekomendasi yang diberikan dalam penelitian ini adalah:

1. Bagi Universitas MuhammadiyahYogyakarta Hasil penelitian ini disarankan dapat menjadi masukan agar dapat menyediakan literatur yang berkaitan dengan layanan bimbingan kelompok untuk meningkatkan motivasi dan rasa percaya diri agar kebutuhan akan referensi dapat terpenuhi sehingga memkasimalkan kajian untuk penelitian selanjutnya.

2. Bagi Siswa

a. Bagi siswa yang mengalami peningkatan motivasi belajar dari kategori rendah menjadi sedang maupun sedang menjadi tinggi diharapkan mampu mengaplikasikan dalam kehidupan sehari-hari sehingga dapat memperbaiki semangat dan mengatasi kesulitan belajar agar dapat meningkatkan prestasi belajar.

b. Bagi siswa yang mengalami peningkatan rasa percaya diri dari kategori sedang menjadi tinggi juga diharapkan lebih meningkatkan keyakinan serta mampu melakukan kontrol terhadap cara berpikir positif dengan meninggalkan hal-hal 
yang dapat merusak kepercayaan diri.

c. Bagi Guru Bimbingan dan Konseling SMP N 15 Yogyakarta, SMP Muhammadiyah 2 Yogyakarta dan MTs N 2 Kota Yogyakarta. Guru bimbingan dan konseling dapat melaksanakan bimbingan kelompok pada siswa yang mengalami masalah yang terkait permasalahan motivasi dan rasa percaya diri sehinga siswa mampu meningkatkan kegiatan belajar.

3. Bagi Peneliti

Hasil penelitian ini memberikan pengalaman untuk merancang penelitian lain yang sejenis dan memberikan pengalaman di lapangan dalam memberikan bimbingan kelompok untuk meningkatkan motivasi belajar dan rasa percaya diri dan mengatasi kesulitan siswa memperbaiki motivasi belajar dan menumbuhkan rasa percaya diri.

4. Bagi Peneliti Selanjutnya

Bagi peneliti yang akan datang diharapkan dapat melakukan penelitian yang lebih baik, dengan mengunakan metode lain seperti konseling individu dan metode yang lainnya.

\section{DAFTAR PUSTAKA}

Slameto. (2012). Belajar dan FaktorFaktor yang Mempengaruhinya. Jakarta: Rineka Cipta.
Djamarah, S.B. (2012). Psikologi Belajar. Jakarta: Rineka Cipta.

Purwanto, M. N. (2013). Psikologi Pendidikan. Bandung Remaja Rosdakarya.

Desmita. (2010). Psikologi Perkembangan Peserta Didik. Bandung: Remaja Rosdakarya.

Davison, G.C. Neale ,J.M dan Kring, A.M (2006). Abnormal Psichology. 9 th Edition. USA.

Anderson, T., Garrison, D. R., dan Archer, W. (2004). Critical Thinking, Cognitive, Presence, Computer Conferencing in Distance Learning. $\quad$ www. $\mathrm{http} / /$ : communityofinquiry.co./file.Co gPres_Final.pdf. Diakses Juli 2016. 